\title{
The Discipline Development of North China Electric Power University Based on ESI
}

\author{
Chen Yuecong \\ Library of North China Electric Power University, \\ Beijing 102206, China; \\ Fang Yanhong \\ Library of North China Electric Power University, \\ Beijing 102206, China;
}

\begin{abstract}
This paper is to study the discipline development of North China Electric Power University (NCEPU) base on the Essential Science Indicators (ESI). It analyzes the field ranking, highly cited papers of NCEPU in ESI. It gives a comparison of the citations of NCEPU and the threshold of ESI top $1 \%$ in six disciplines. Finally it gives a suggestion of discipline development of NCEPU.
\end{abstract}

Keywords: ESI Discipline Development Analysis

\section{INTRODUCTION}

Essential Science Indicators (ESI) is one of ISI/Thomson's Web of Knowledge databases. It is a web-based and basic analysis and evaluation tool that was published by the world's famous Institute for Scientific Information (ISI) in 2001 to measure the performance of scientific researches

\section{Zhu Zhengmao}

The Sci-tech Academy of North China Electric Power University, Beijing 102206, China

Qi Hongjing

The Sci-tech Academy of North China Electric Power University, Beijing 102206, China

and track the trend of scientific development. It is the quantitative analysis database that is established based on more than 10 million papers in over 11,000 kinds of academic journals in the world that are included in $\mathrm{SCl}$ (Science Citation Index Expanded) and SSCI (Social Sciences Citation Index). ESI has become one of the most important indicators to evaluate the international academic research level and influence of the colleges and universities, academic institutions, countries/regions, etc.

Three types of papers (Article, Review and Note) of SCIE and SSCI in Web of Science are included in ESI database. ESI is a ten-year rolling database and is updated every two months, which is in Jan. Mar. May. July. Sep. Nov. of each year. The data of over 11,000 kinds of academic journals are divided into 22 specific fields of research, which are in Tab 1.

Tab.1: The 22 specific fields of ESI

\begin{tabular}{|c|c|}
\hline - Agricultural Science & - Mathematics \\
\hline - Biology \& Biochemistry & - Microbiology \\
\hline - Chemistry & - Molecular Biology \& Genetics \\
\hline - Clinical Medicine & - Multidisciplinary * \\
\hline - Computer Science & - Neuroscience \& Behavior \\
\hline - Economics \& Business & - Pharmacology \\
\hline - Engineering & - Physics \\
\hline - Environment/ Ecology & - Plant \& Animal Science \\
\hline - Geosciences & - Psychiatry/Psychology \\
\hline - Immunology & - Social Sciences--general \\
\hline - Materials Science & - Space Science \\
\hline
\end{tabular}


ESI identifies the journal articles, scientists, institutions, countries, and journals by setting threshold as selection criteria (a certain number of total citations) for each of the disciplines. These thresholds, set to select some constant fraction of items, are described in an accompanying document (citation thresholds). Field rankings for scientists, institutions, countries, and journals are provided in ESI.

Scientists: Of the roughly 4 million scientists' names appearing in the 10 years of Thomson Reuters data surveyed, about 60,000 scientists are listed in ESI which represents the top $1 \%$ of authors in terms of total citations in each of the disciplines over the 10 years.

Institutions : About 700,000 institutional affiliations are scanned in the 10-year data file, and about 4,000 of these are selected for ESI, also representing the top $1 \%$ in each discipline (unification of institutional names is undertaken to obtain more accurate statistics).

Countries and journals: About 150 are selected out of about 200 scanned, and for journals about 5,000 of the 10,000 , both representing the top $50 \%$ by discipline and total citations over the 10-year period.

ESI also provide the search of highly cited papers and hot papers.

Highly cited papers: Lists the top cited papers over the last 10 years in 22 scientific fields.
Rankings are based on meeting a threshold of the top $1 \%$ by field and year based on total citations received.

Hot Papers: Papers published in the past two years that receive more citations during the past two months relative to other papers in the same field. About 1,800 hot papers are selected, representing the top $0.1 \%$ in the two-year period.

This paper analyzed the ESI ranking of NCPU and the discipline in the top $1 \%$ of the world. The highly cited papers of NCEPU were also listed and studied. The statistics of these papers are analyzed according to years, disciplines, citations and departments. It listed the six disciplines which publish the most papers in NCEPU and compared the citations of each discipline and the threshold of ESI top $1 \%$ of the world ${ }^{[1-2,5-14]}$.

\section{The disciplines in ESI top 1\% of NCEPU}

According to the newest ESI data updated on May 7, 2015, the ENGINEERING discipline of NCEPU is the only discipline in the top $1 \%$ of the world of ESI. As in ESI statistics, NCEPU ranks $366^{\text {th }}$ of all 1151 institutions that in the world top $1 \%$ list of ESI. There are 838 papers with total 6742 citations and average citations 8.05 per paper in the period of January 1, 2005-February 28,2015 . Of all the 22 fields/disciplines in ESI, NCEPU with 17395 total citations ranks $2149^{\text {th }}$ among all 4678 institutions in the top 1\% ESI ranking $^{[3-4]}$. All these statistics are in Tab.2.

Tab.2: The ESI ranking of ESI

\begin{tabular}{|c|c|c|c|c|c|c|}
\hline Field & Papers & Citations & $\begin{array}{c}\text { Citations per } \\
\text { paper }\end{array}$ & Ranking & $\begin{array}{c}\text { Number of } \\
\text { institutions } \\
\text { in top 1\% }\end{array}$ & $\begin{array}{c}\text { Ranking } \\
\text { percentage }\end{array}$ \\
\hline ENGINEERING & 838 & 6742 & 8.05 & 366 & 1151 & $31.80 \%$ \\
\hline All fields & 2077 & 17395 & 8.38 & 2149 & 4678 & $45.94 \%$ \\
\hline
\end{tabular}

In the ENGINEERING field the top 10 institutions are as in Fig.1, Chinese Acad SCl, Tsing Hua Univ, Nanyang Technol Univ and
Nanyang Technol Univ-NIE are ranked $4^{\text {th }}, 7^{\text {th }}, 8^{\text {th }}$, $9^{\text {th }}$. There are big differences in the papers and citations of NCEPU and these institutions. 


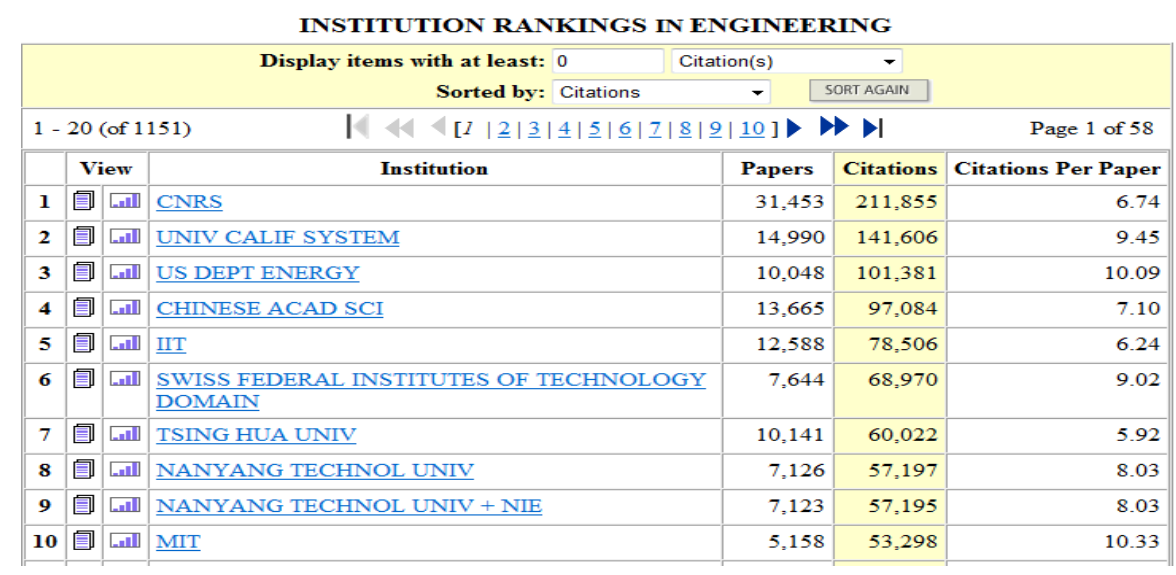

Fig. 1 The top 10 institutions in ENGINEERING field

\section{The highly cited papers of NCEPU}

According to the newest ESI data updated on
May 7, 2015, there are 32 highly cited papers, which are in Tab.3.

Tab. 3: The highly cited papers of NCEPU

\begin{tabular}{|c|c|c|c|c|}
\hline $\begin{array}{c}\text { Title } \\
\end{array}$ & Authors in NCEPU & Source & Citations & Years \\
\hline $\begin{array}{c}\text { OBSERVATION OF ELECTRON-ANTINEUTRINO } \\
\text { DISAPPEARANCE AT DAYA BAY }\end{array}$ & $\begin{array}{c}\text { Chen, Y. X.; Ma, X. B.; Wang, L. } \\
\text { Z. }\end{array}$ & PHYS REV LETT & 618 & 2012 \\
\hline $\begin{array}{l}\text { REVIEW ON MULTI-CRITERIA DECISION ANALYSIS AID IN } \\
\text { SUSTAINABLE ENERGY DECISION-MAKING }\end{array}$ & $\begin{array}{l}\text { WANG JJ; JING YY; ZHANG } \\
\text { CF; ZHAO JH }\end{array}$ & $\begin{array}{l}\text { RENEW SUSTAIN } \\
\text { ENERGY REV }\end{array}$ & 174 & 2009 \\
\hline $\begin{array}{c}\text { HIGH-PERFORMANCE INVERTED POLYMER SOLAR } \\
\text { CELLS WITH SOLUTION-PROCESSED TITANIUM } \\
\text { CHELATE AS ELECTRON-COLLECTING LAYER ON ITO } \\
\text { ELECTRODE }\end{array}$ & \begin{tabular}{|c|} 
TAN ZA; ZHANG \\
WQ; ZHANG ZG; QIAN \\
DP; HUANG Y; HOU JH; LI \\
YF
\end{tabular} & ADVAN MATER & 141 & 2012 \\
\hline $\begin{array}{l}\text { THE PARAMETERIZATION REDUCTION OF SOFT SETS } \\
\text { AND ITS APPLICATIONS }\end{array}$ & $\begin{array}{l}\text { CHEN DG; TSANG } \\
\text { ECC; YEUNG DS; WANG XZ }\end{array}$ & $\begin{array}{c}\text { COMPUT MATH } \\
\text { APPL }\end{array}$ & 139 & 2005 \\
\hline $\begin{array}{c}\text { ENERGY CONSUMPTION, CARBON EMISSIONS, AND } \\
\text { ECONOMIC GROWTH IN CHINA }\end{array}$ & ZHANG XP; CHENG XM & ECOL ECON & 131 & 2009 \\
\hline $\begin{array}{c}\text { ADSORPTION OF COPPER(II) ON MULTIWALLED } \\
\text { CARBON NANOTUBES IN THE ABSENCE AND } \\
\text { PRESENCE OF HUMIC OR FULVIC ACIDS }\end{array}$ & $\begin{array}{l}\text { SHENG GD; LI JX; SHAO } \\
\text { DD; HU J; CHEN CL; CHEN } \\
\text { YX; WANG XK }\end{array}$ & $\begin{array}{l}\text { J HAZARD } \\
\text { MATER }\end{array}$ & 119 & 2010 \\
\hline $\begin{array}{l}\text { SORPTION OF NI(II) ON GMZ BENTONITE: EFFECTS OF } \\
\text { PH, IONIC STRENGTH, FOREIGN IONS, HUMIC ACID AND } \\
\text { TEMPERATURE110 }\end{array}$ & $\begin{array}{l}\text { YANG ST; LI JX; LU Y; } \\
\text { CHEN YX; WANG XK }\end{array}$ & $\begin{array}{l}\text { APPL RADIAT } \\
\text { ISOTOPES }\end{array}$ & 111 & 2009 \\
\hline $\begin{array}{c}\text { KINETICS AND THERMODYNAMICS OF ADSORPTION OF } \\
\text { IONIZABLE AROMATIC COMPOUNDS FROM AQUEOUS } \\
\text { SOLUTIONS BY AS-PREPARED AND OXIDIZED } \\
\text { MULTIWALLED CARBON NANOTUBES }\end{array}$ & $\begin{array}{l}\text { SHENG GD; SHAO DD; REN } \\
\text { XM; WANG XQ; LI } \\
\text { JX; CHEN YX; WANG XK }\end{array}$ & $\begin{array}{l}\text { J HAZARD } \\
\text { MATER }\end{array}$ & 108 & 2010 \\
\hline $\begin{array}{c}\text { ENERGY CONSUMPTION AND ECONOMIC GROWTH: } \\
\text { EVIDENCE FROM CHINA AT BOTH AGGREGATED AND } \\
\text { DISAGGREGATED LEVELS }\end{array}$ & $\begin{array}{c}\text { YUAN JH; KANG JG; ZHAO } \\
\text { CH; HU ZG }\end{array}$ & ENERG ECON & 105 & 2008 \\
\hline ON THE GENERALIZATION OF FUZZY ROUGH SETS & $\begin{array}{l}\text { YEUNG DS; CHEN } \\
\text { DG; TSANG ECC; LEE } \\
\text { JWT; WANG XZ }\end{array}$ & $\begin{array}{l}\text { IEEE TRANS } \\
\text { FUZZY SYST }\end{array}$ & 98 & 2005 \\
\hline $\begin{array}{c}\text { CONVERGENCE THEOREMS OF FIXED POINTS FOR } \\
\text { KAPPA-STRICT PSEUDO-CONTRACTIONS IN HILBERT } \\
\text { SPACES }\end{array}$ & ZHOU HY & $\begin{array}{l}\text { NONLINEAR } \\
\text { ANAL-THEOR } \\
\text { METH APP }\end{array}$ & 92 & 2008 \\
\hline $\begin{array}{c}\text { IMPROVED MEASUREMENT OF ELECTRON } \\
\text { ANTINEUTRINO DISAPPEARANCE AT DAYA BAY }\end{array}$ & $\begin{array}{l}\text { Chen, Y. X.; Ma, X. B.; Wang, L. } \\
\text { Z. }\end{array}$ & CHIN PHYS C & 91 & 2013 \\
\hline $\begin{array}{l}\text { ECOLOGICAL RISK ASSESSMENT OF HEAVY METALS IN } \\
\text { SEDIMENT AND HUMAN HEALTH RISK ASSESSMENT OF } \\
\text { HEAVY METALS IN FISHES IN THE MIDDLE AND LOWER } \\
\text { REACHES OF THE YANGTZE RIVER BASIN }\end{array}$ & YI YJ; YANG ZF; ZHANG SH & $\begin{array}{l}\text { ENVIRON } \\
\text { POLLUT }\end{array}$ & 88 & 2011 \\
\hline $\begin{array}{l}\text { ADSORPTION OF EU(III) ONTO TIO2: EFFECT OF PH, } \\
\text { CONCENTRATION, IONIC STRENGTH AND SOIL FULVIC } \\
\text { ACID }\end{array}$ & $\begin{array}{l}\text { TAN XL; FANG M; LI JX; LU Y; } \\
\text { WANG XK }\end{array}$ & $\begin{array}{l}\text { J HAZARD } \\
\text { MATER }\end{array}$ & 84 & 2009 \\
\hline $\begin{array}{l}\text { SORPTION OF COPPER(II) ONTO SUPER-ADSORBENT } \\
\text { OF BENTONITE-POLYACRYLAMIDE COMPOSITES }\end{array}$ & $\begin{array}{c}\text { ZHAO GX; ZHANG HX; FAN } \\
\text { QH; REN XM; LI JX; CHEN YX; } \\
\text { WANG XK }\end{array}$ & $\begin{array}{l}\text { J HAZARD } \\
\text { MATER }\end{array}$ & 79 & 2010 \\
\hline $\begin{array}{c}\text { HIGHLY EMISSIVE AND COLOR-TUNABLE } \\
\text { CUINS2-BASED COLLOIDAL SEMICONDUCTOR } \\
\text { NANOCRYSTALS: OFF-STOICHIOMETRY EFFECTS AND }\end{array}$ & $\begin{array}{l}\text { CHEN BK; ZHONG HZ; ZHANG } \\
\text { WQ; TAN ZA; LI YF; YU CR; } \\
\text { ZHAI TY; BANDO YS; YANG } \\
\end{array}$ & $\begin{array}{c}\text { ADV FUNCT } \\
\text { MATER }\end{array}$ & 73 & 2012 \\
\hline
\end{tabular}




\begin{tabular}{|c|c|c|c|c|}
\hline IMPROVED ELECTROLUMINESCENCE PERFORMANCE & SY; ZOU BS & & & \\
\hline $\begin{array}{c}\text { OPTIMIZATION OF CAPACITY AND OPERATION FOR } \\
\text { CCHP SYSTEM BY GENETIC ALGORITHM } \\
\end{array}$ & WANG JJ; JING YY; ZHANG CF & APPL ENERG & 60 & 2010 \\
\hline $\begin{array}{c}\text { THE OPTIMAL EVAPORATION TEMPERATURE AND } \\
\text { WORKING FLUIDS FOR SUBCRITICAL ORGANIC } \\
\text { RANKINE CYCLE }\end{array}$ & $\begin{array}{l}\text { HE C; LIU C; GAO H; XIE H; LI } \\
\text { YR; WU SY; XU JL }\end{array}$ & ENERGY & 53 & 2012 \\
\hline $\begin{array}{l}\text { WHY DID CHINAS ENERGY INTENSITY INCREASE } \\
\text { DURING 1998-2006: DECOMPOSITION AND POLICY } \\
\text { ANALYSIS }\end{array}$ & ZHAO XL; MA CB; HONG DY & ENERG POLICY & 53 & 2010 \\
\hline $\begin{array}{l}\text { CONVERGENCE THEOREMS OF FIXED POINTS FOR } \\
\text { LIPSCHITZ PSEUDO-CONTRACTIONS IN HILBERT } \\
\text { SPACES }\end{array}$ & ZHOU HY & $\begin{array}{l}\text { J MATH ANAL } \\
\text { APPL }\end{array}$ & 52 & 2008 \\
\hline $\begin{array}{l}\text { ADVANCES AND TRENDS OF ENERGY STORAGE } \\
\text { TECHNOLOGY IN MICROGRID }\end{array}$ & TAN XG; LI QM; WANG H & $\begin{array}{c}\text { INT J ELEC } \\
\text { POWER ENERG } \\
\text { SYST }\end{array}$ & 46 & 2013 \\
\hline $\begin{array}{l}\text { MAKING FISCHER-TROPSCH FUELS AND ELECTRICITY } \\
\text { FROM COAL AND BIOMASS: PERFORMANCE AND COST } \\
\text { ANALYSIS }\end{array}$ & $\begin{array}{c}\text { LIU GJ; LARSON ED; } \\
\text { WILLIAMS RH; KREUTZ TG; } \\
\text { GUO XB }\end{array}$ & ENERG FUEL & 46 & 2011 \\
\hline $\begin{array}{c}\text { GENERALIZED H-2 FAULT DETECTION FOR } \\
\text { TWO-DIMENSIONAL MARKOVIAN JUMP SYSTEMS }\end{array}$ & $\begin{array}{c}\text { WU LG; } \\
\underset{W X}{\text { YAO XM; }} \quad \text { ZHENG }\end{array}$ & AUTOMATICA & 45 & 2012 \\
\hline $\begin{array}{r}\text { FORECASTING STOCK INDICES USING RADIAL BASIS } \\
\text { FISH SWAR }\end{array}$ & 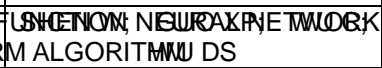 & $\begin{array}{l}\text { SKOFUUWUIZAASBD A } \\
\text { SYST }\end{array}$ & 2TIELC & 2011 \\
\hline $\begin{array}{l}\text { THERMAL CONDUCTIVITIES STUDY ON SILICA } \\
\text { AEROGEL AND ITS COMPOSITE INSULATION } \\
\text { MATERIALS }\end{array}$ & $\begin{array}{l}\text { WEI GS; LIU YS; ZHANG } \\
\text { XX; YU F; DU XZ }\end{array}$ & $\begin{array}{l}\text { INT J HEAT MASS } \\
\text { TRANSFER }\end{array}$ & 42 & 2011 \\
\hline $\begin{array}{l}\text { COMMON FIXED POINT THEOREMS ON GENERALIZED } \\
\text { DISTANCE IN ORDERED CONE METRIC SPACES }\end{array}$ & $\begin{array}{c}\text { CHO YJ; SAADATI R; } \\
\text { WANG SH }\end{array}$ & $\begin{array}{l}\text { COMPUT MATH } \\
\text { APPL }\end{array}$ & 39 & 2011 \\
\hline $\begin{array}{c}\text { SPECTRAL MEASUREMENT OF ELECTRON } \\
\text { ANTINEUTRINO OSCILLATION AMPLITUDE AND } \\
\text { FREQUENCY AT DAYA BAY }\end{array}$ & $\begin{array}{l}\text { Chen, Y. X.; Ma, X. B.; Wang, L. } \\
\text { Z. }\end{array}$ & PHYS REV LETT & 35 & 2014 \\
\hline $\begin{array}{c}\text { EFFICIENT AND STABLE POLYMER SOLAR CELLS WITH } \\
\text { SOLUTION-PROCESSED MOLYBDENUM OXIDE } \\
\text { INTERFACIAL LAYER }\end{array}$ & $\begin{array}{l}\text { TAN ZA; } \quad \text { QIAN DP; } \quad \text { ZHANG } \\
\text { WQ; LI LJ; DING YQ; XU } \\
\text { Q; WANG FZ; LI YF }\end{array}$ & J MATER CHEM A & 30 & 2013 \\
\hline $\begin{array}{l}\text { NEW EXISTENCE RESULTS FOR HIGHER-ORDER } \\
\text { NONLINEAR FRACTIONAL DIFFERENTIAL EQUATION } \\
\text { WITH INTEGRAL BOUNDARY CONDITIONS }\end{array}$ & $\begin{array}{ll}\text { FENG MQ; } & \text { ZHANG XM; GE } \\
& \text { WG }\end{array}$ & $\begin{array}{l}\text { BOUND VALUE } \\
\text { PROBL }\end{array}$ & 28 & 2011 \\
\hline $\begin{array}{l}\text { CHARACTERISTICS AND MECHANISM STUDY OF } \\
\text { ANALYTICAL FAST PYROLYSIS OF POPLAR WOOD }\end{array}$ & $\begin{array}{c}\text { DONG CQ; } \text { ZHANG ZF; LU } \\
\text { Q; YANG YP }\end{array}$ & $\begin{array}{l}\text { ENERG CONV } \\
\text { MANAGE }\end{array}$ & 26 & 2012 \\
\hline $\begin{array}{l}\text { OPTIMAL GEOMETRIC STRUCTURE FOR } \\
\text { NANOFLUID-COOLED MICROCHANNEL HEAT SINK } \\
\text { UNDER VARIOUS CONSTRAINT CONDITIONS }\end{array}$ & WANG XD; AN B; XU JH & $\begin{array}{l}\text { ENERG CONV } \\
\text { MANAGE }\end{array}$ & 19 & 2013 \\
\hline $\begin{array}{c}\text { A HYBRID ANNUAL POWER LOAD FORECASTING } \\
\text { MODEL BASED ON GENERALIZED REGRESSION } \\
\text { NEURAL NETWORK WITH FRUIT FLY OPTIMIZATION } \\
\text { ALGORITHM }\end{array}$ & 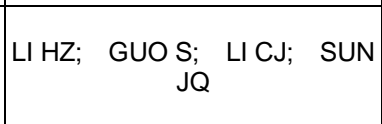 & $\begin{array}{l}\text { KNOWL-BASED } \\
\text { SYST }\end{array}$ & 13 & 2013 \\
\hline
\end{tabular}

3.1 The statistics of publication years of the highly cited papers of NCEPU

The publication years of the 32 papers are mainly in 2010-2013 and an increasing trend are shown in 2005-2011. There is only one paper in 2014 because the age is closer.

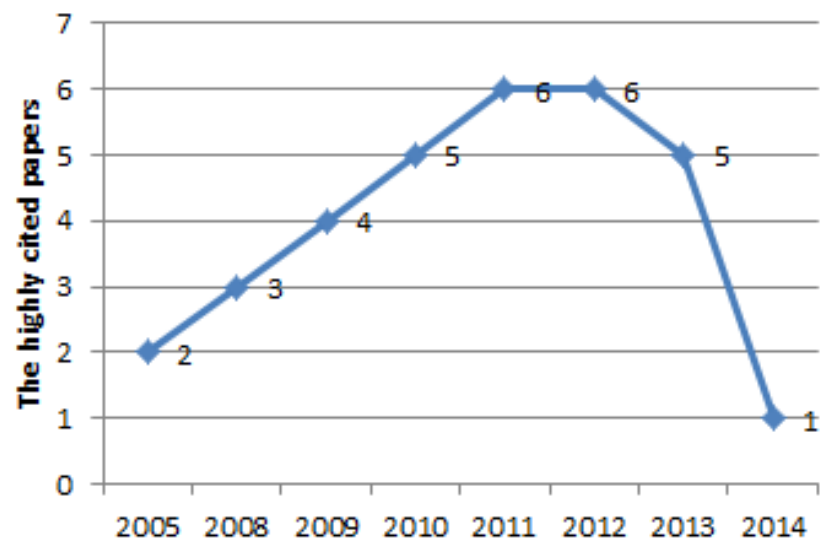

Fig.2 Publication years of the highly cited papers of NCEPU 
3.2 The disciplines and departments of the highly cited papers of NCEPU

The highly cited papers of NCEPU are mainly in disciplines of ENGINEERING, MATHEMATICS, PHYSICS, MATERIALS SCIENCE, ENVIRONMENT/ECOLOGY, ECONOMICS \&
BUSINESS, COMPUTER SCIENCE and SOCIAL SCIENCES, GENERAL. ENGINEERING discipline, with the most papers, has 13 highly cited papers and is the only discipline in top $1 \%$ of NCEPU.

Tab.4: The disciplines and departments of the highly cited papers of NCEPU

\begin{tabular}{|c|c|c|}
\hline Field & $\begin{array}{l}\text { The number of } \\
\text { highly cited papers }\end{array}$ & $\begin{array}{c}\text { The number of papers in corresponding } \\
\text { department }\end{array}$ \\
\hline ENGINEERING & 13 & $\begin{array}{c}\text { School of Energy Power and Mechanical Engineering } \\
\text { (4 papers), School of Nuclear Science and } \\
\text { Engineering( } 4 \text { papers), Renewable Energy School(2 } \\
\text { papers), School of Electrical \& Electronic } \\
\text { Engineering( } 1 \text { paper), School of Mathematics \& } \\
\text { Physics ( } 1 \text { paper), School of Control and Computer } \\
\text { Engineering(1 paper) }\end{array}$ \\
\hline MATHEMATICS & 5 & School of Mathematics \& Physics (5 papers) \\
\hline PHYSICS & 4 & $\begin{array}{l}\text { School of Energy Power and Mechanical Engineering } \\
\text { ( } 2 \text { papers), Renewable Energy School( } 2 \text { papers) }\end{array}$ \\
\hline $\begin{array}{l}\text { MATERIALS } \\
\text { SCIENCE }\end{array}$ & 3 & Renewable Energy School(3 papers) \\
\hline $\begin{array}{c}\text { ENVIRONMENT/EC } \\
\text { OLOGY }\end{array}$ & 2 & $\begin{array}{c}\text { School of Energy Power and Mechanical Engineering } \\
\text { (1 paper), School of Economic \& Management( } 1 \\
\text { paper) }\end{array}$ \\
\hline $\begin{array}{c}\text { ECONOMICS \& } \\
\text { BUSINESS }\end{array}$ & 2 & School of Economic \& Management( 2 papers) \\
\hline $\begin{array}{l}\text { COMPUTER } \\
\text { SCIENCE }\end{array}$ & 2 & School of Economic \& Management( 2 papers) \\
\hline $\begin{array}{c}\text { SOCIAL SCIENCES, } \\
\text { GENERAL }\end{array}$ & 1 & School of Economic \& Management(1 paper) \\
\hline
\end{tabular}

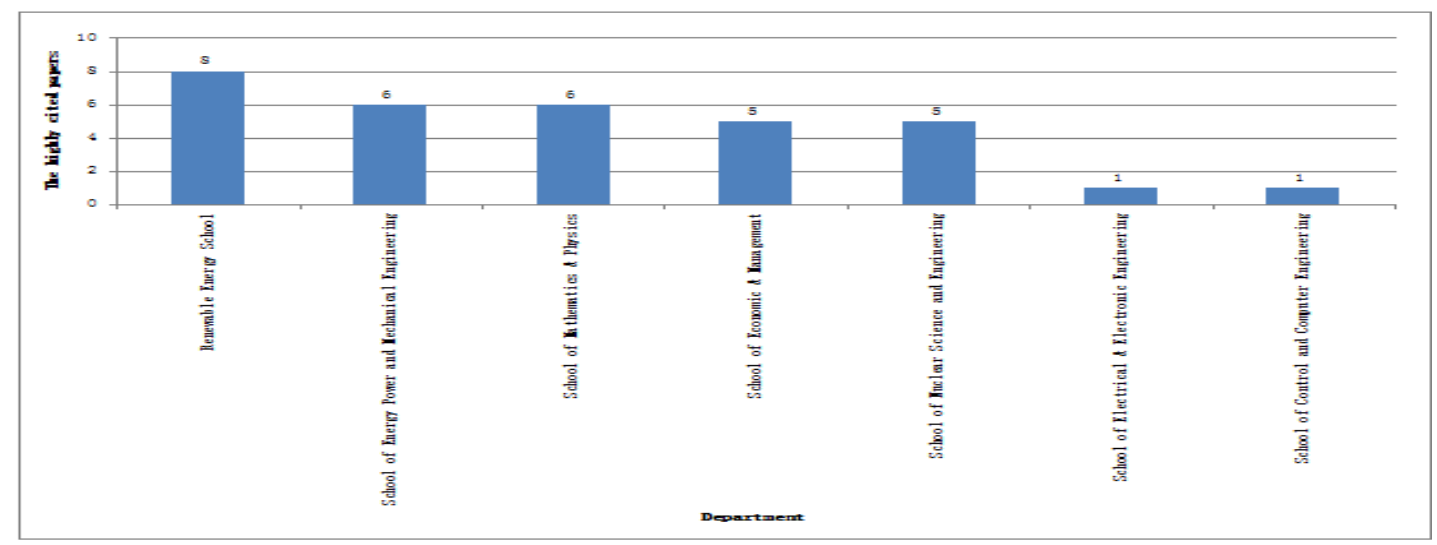

Fig.3 The departments of the highly cited papers of NCEPU

3.3 The cooperative countries/territories and institutions of highly cited papers of NCEPU

There are 9 papers cooperated with other countries/territories besides China and Hong Kong, China. The countries are mainly in USA, TAIWAN, RUSSIA, CZECH REPUBLIC, etc. which are in Tab.5. 
Tab.5: The cooperative countries/territories of highly cited papers of NCEPU

\begin{tabular}{|c|c|c|}
\hline Countries/Territories & Papers cooperated & The percentage of cooperation \\
\hline USA & 5 & $23.81 \%$ \\
\hline TAIWAN & 3 & $14.29 \%$ \\
\hline RUSSIA & 3 & $14.29 \%$ \\
\hline CZECH REPUBLIC & 3 & $14.29 \%$ \\
\hline AUSTRALIA & 2 & $9.52 \%$ \\
\hline SOUTH KOREA & 1 & $4.76 \%$ \\
\hline JAPAN & 1 & $4.76 \%$ \\
\hline IRAN & 1 & $4.76 \%$ \\
\hline ICELAND & 1 & $4.76 \%$ \\
\hline
\end{tabular}

There are 62 cooperative research institutions Shandong Univ, Princeton Univ, etc. of 32 papers. The most are Chinese Acad $\mathrm{SCl}$,

Tab.6: The cooperative institutions of highly cited papers of NCEPU

\begin{tabular}{|c|c|c|}
\hline Institutions & Papers cooperated & The percentage of cooperation \\
\hline CHINESE ACAD SCI & 9 & $6.12 \%$ \\
\hline SHANDONG UNIV & 4 & $2.72 \%$ \\
\hline PRINCETON UNIV & 4 & $2.72 \%$ \\
\hline BEIJING NORMAL UNIV & 4 & $2.72 \%$ \\
\hline VIRGINIA TECH & 3 & $2.04 \%$ \\
\hline UNIV WISCONSIN & 3 & $2.04 \%$ \\
\hline UNIV SCI TECHNOL & 3 & $2.04 \%$ \\
\hline CHINA & 3 & $2.04 \%$ \\
\hline UNIV ILLINOIS & 3 & $2.04 \%$ \\
\hline UNIV HOUSTON & 3 & $2.04 \%$ \\
\hline UNIV HONG KONG & & \\
\hline
\end{tabular}

3.4 The global influence of highly cited papers of NCEPU

This paper counted the citations of NCEPU highly cited papers in Web Of Science. There are 3009 citing papers in Web of Science Core Collection that cited the 32 highly cited papers of NCEPU. The citing papers are from over 100 countries and territories: USA (394), Korea (192), Japan (179), India (163), Germany (158), Italy (147), etc. These statistics show that the highly cited papers of NCEPU have certain global influence in the world.

\section{The difference between NCEPU and ESI top} $1 \%$ of the world

Based on the data of Web Of Science, this paper analyzed the papers of SCIE and SSCI from 2005 to 2015, and classified the papers into 22 ESI fields. The most fields are ENGINEERING, PHYSICS, MATHEMATICS, CHEMISTRY, ENVIRONMENT/ECOLOGY, MATERIALS SCIENCE and COMPUTER SCIENCE. The ENGINEERING field is already in top $1 \%$ of the world, so we counted the citation papers the other six fields and compared them with the ESI thresholds which are in Tab.9. 
Tab. 7: The comparison of six disciplines of NCEPU with ESI thresholds

\begin{tabular}{|c|c|c|c|c|}
\hline Field & Papers & $\begin{array}{c}\text { Web Of Science } \\
\text { citations }\end{array}$ & ESI thresholds & Differences \\
\hline PHYSICS & 478 & 4328 & 10453 & $-58.60 \%$ \\
\hline MATHEMATICS & 271 & 2061 & 3437 & $-40.03 \%$ \\
\hline CHEMISTRY & 245 & 2735 & 5510 & $-50.36 \%$ \\
\hline ENVIRONMENT/ECOLOGY & 291 & 3707 & 3208 & $15.55 \%$ \\
\hline MATERIALS SCIENCE & 215 & 1583 & 3150 & $-49.75 \%$ \\
\hline COMPUTER SCIENCE & 156 & 1967 & 2276 & $-13.58 \%$ \\
\hline
\end{tabular}

According to Tab.7, the ENVIRONMENT/ECOLOGY and COMPUTER SCIENCE disciplines are near to the ESI thresholds. But there is something to be noticed. The Web Of Science citations is different from the ESI citations, the former are citations from Web Of Science Core Collection, but the latter ESI citations are citations from SCIE and SSCI. In addition, the data of Tab.9 is from 2005 to 2015 , while the ESI data on May 7, 2015 is in the period of January 1, 2005-February 28, 2015. So the Web Of Science citations in Tab.9 is bigger than the ESI citations, so there is some difference of the data.

\section{Conclusions}

According to the newest ESI data, ENGINEERING is the only discipline in the top $1 \%$ of the world and NCEPU ranks $366^{\text {th }}$ of all 1151 institutions. There are 32 highly cited papers of ESI in NCEPU, which have certain global influence in the world. And the citations of ENVIRONMENT/ECOLOGY and COMPUTER SCIENCE disciplines in this paper's statistics are near to the ESI thresholds.

\section{References}

[1] Baidu Encyclopedia [EB/OL]. http://baike.bai du.com/link?url=T5wRtRGvsGQal0GOg43fyv6 RTaU2KZvw5auNVJvmnicllqpggETjmqATwtu bd5y40zOBpSTgPj-abSkEJLIzpac3t1jpsyUuns bwNHAuW2S.

[2] Baidu Wenku. The Using Methods ofESI [E
B/OL]. http://wenku.baidu.com/link?url=xJibjxy bE5bIR4DiAtnmVDNEgnOLJbccJ6fJriPf6dCNI g8EDD9W1 rrZfIEvJ6AGCIFUDZlggeKQZecfB ba9Q96iTJXibQSgSPS66ejkmqC.

[3] Dong zheng'e, Chen Huilan. Investigation in to Library Service Module of University $\mathrm{Di}$ scipline Evaluation On the Basis of ESI an d Incites Database [J]. Library Journal,2014, 11:23-28.

[4] Dong zheng-e, Chen Hui-lan. Analysis on t he Discipline Construction in Donhua Univer sity in Terms of ESI and SCI-E Indexed Jo urnal Rank in Categories [J]. Journal of Do nghua University(Natural Science), 2012,01: 107-112.

[5] Essential Science Indicators [EB/OL].http://e si.webofknowledge.com/home.cgi.

[6] Web Of Science [EB/OL]. http://www.webofk nowledge.com.

[7] Essential Science Indicators[EB/OL]. http://w okinfo.com/products_tools/analytical/essential scienceindicators/

[8] METHODOLGY FOR SCIENCEWATCH.CO $\mathrm{M}[\mathrm{EB} / \mathrm{OL}$ ]. http://archive.sciencewatch.com/ab out $/$ met/.

[9] Essential Science Indicators[EB/OL]. http://w okinfo.com/products_tools/analytical/essential scienceindicators/

[10]CITATION THRESHOLDS [EB/OL]. http://ar chive.sciencewatch.com/about/met/thresholds/ [11]ESSENTIAL SCIENCE INDICATORSS[EB/O L]. http://ip-science.thomsonreuters.com/m/pd 
fs/mgr/qrc_esi_mar09.pdf

[12]Database : Essential Science Indicators (E

SI) [EB/OL]. http://www.usc.edu/libraries/data bases/records/database.php?db=BNS

[13]ISI Web of Knowledge Help [EB/OL]. http://
images.webofknowledge.com/WOK46/help/W

OK/h_aresources.html

[14]ESI (Essential Science Indicators) [EB/OL]. http://www.eisz.hu/en/licenszek/osszes/esi-en/ licensz.html 